\title{
The Relationship between EFL Learners' Metacognitive Strategies, and Their Critical Thinking
}

\author{
Bahador Sadeghi (Corresponding Author) \\ English Department, Islamic Azad University, Takestan Branch, Takestan, Iran \\ Mohammad Taghi Hassani \\ Imam Hossein University, Iran; \\ English Department, Islamic Azad University, Takestan Branch, Takestan, Iran \\ Masoumeh Rahmatkhah \\ English Department, Islamic Azad University, Takestan Branch, Takestan, Iran
}

\begin{abstract}
The present study investigates the the relationship between metacognition and critical thinking in language learning. 102 intermediate students from 2 language institutions in Rasht were selected. Data were gathered by means of two questionnaires and were analyzed using Pearson Correlation procedures. Results indicated that there was a positive correlation between metacognition and critical thinking. In other words, the more metacognitive strategies increase in students, the more critical thinking enhances as well. A comparison of gender differences was done too. The mean scores of male and female participants' critical thinking and metacognitive strategies were investigated. The mean score of male participants' critical thinking and metacognitive strategies was more from the mean score of the female participants.
\end{abstract}

Index Terms—critical thinking, metacognition strategies, MSQIT, CCTST

\section{INTRODUCTION}

The concept of metacognition and critical thinking are two important aspects of the learner in improving language learning. Critical thinking is awareness of one's own thinking and reflection on the thinking of self and others as objects of cognition $(\mathrm{Ku}, 2009)$. Metacognition was defined as thinking about one's thinking through a cyclical process of analyzing, self-monitoring and evaluating one's response to information in an effort to more clearly understand new knowledge (Sternberg, 1998).

Study of critical thinking and metacognition has become very important. Metacognitive skills are valuable to students and they foster critical thinking-most teachers know little about how to include metacognitive skills in course curricula (Pellegrino, 2007). Metacognition and critical thinking are two important factors in the development of language learning of EFL learners. As such, it is necessary to carry out further research to understand more about them and their relationship with other variables such as age, gender, motivation, anxiety and so on. One of the objects of education is for students to think critically. In order to achieve this end, it is important to identify certain metacognitive factors that can facilitate it. As such, this study emphasizes on the role of EFL learners' metacognitive strategies and their critical thinking skills.

\section{LITERATURE REVIEW}

\section{A. Metacognition}

The term metacognition has been variously defined by different people. Flavell (1979) defined metacognition as "the individuals' knowledge about cognitive processes and the application of this knowledge for controlling the cognitive process." Young (1991) stated that metacognition is the ability to control one's own thinking processes in problem solving.

It is often argued that the importance of metacognition is in its potential to explore, explain and ultimately to improve students' thinking and learning processes (White, 1988).

Kuhn defined metacognition as, "Enhancing (a) metacognitive awareness of what one believes and how one knows and (b) metastrategic control in application of the strategies that process new information"

Taylor (1999) defines metacognition as "an appreciation of what one already knows, together with a correct apprehension of the learning task and what knowledge and skills it requires, combined with the agility to make correct inferences about how to apply one's strategic knowledge to a particular situation, and to do so efficiently and reliably." 
According to Flavell (1979) there are four model of metacognition: (1) metacognitive knowledge, (2) metacognitive experiences, (3) goals/tasks, and (4) actions/strategies. He said that people monitor their cognitive process by using components described in these four categories.

Another metacognitive model by Winne and Hadwin (1998) has four basic stages: task definition, goal setting and planning, enactment, and adaptation. Their model suggests that the learner generates a perception of what the task is and the available resources, makes a plan for addressing the task, enacts study strategies, and makes changes to his or her cognitive structure based on perceptions of performance.

The assessment of metacognition is made intrinsically difficult because it is not an overt behavior; it is not only arrays of inner processes but rather often individuals are not completely aware of them. (Sandí-Ureña, 2008).

In an investigation of students' use of metacognitive strategies by Iranian EFL learners in doing various tasks across different proficiency levels, Torkamani (2010) found that, there was significant difference among the participants of various proficiency levels in their choice of metacognitive strategies due to the impact of language proficiency level.

In another study, Rahimi and Katal (2010) investigated metacognitive strategies awareness and success in learning English as a foreign language. According to this research, metacognitive learners who take conscious steps to understand what they are doing when they learn are the most successful learners. Rahimi studied some theories and practices in the field of metacognitive knowledge and language learning. She believes that the use of metacognitive strategies allows learners to plan, control and evaluate learning that helps them gain better achievement and better learning results.

Iwai (2011) investigated the effects of metacognitive strategies on the teaching of reading for English as a Foreign Language (EFL) and English as a Second Language (ESL). This study focused on metacognitive reading strategies for these learners, first presenting the concept of metacognition as proposed by Flavell, and then going on to explain reading strategies that require metacognitive skills within three knowledge dimensions: declarative, procedural, and conditional. She believed that teaching metacognitive strategies is a key for success and teaching strategies, step by step is important. In her idea, EFL/ESL teachers should use diverse metacognitive techniques during classroom instruction. Also, teachers are encouraged to model metacognitive strategies, supporting students as they learn how to use them, and then reducing that support as students learn how to use them independently.

Noroozi and Soozandehfar (2011) investigated about metacognitive awareness of reading strategies and reading comprehension. This study was done with 40 university students of English and used two tests (Kruskal-Wallis \& Pearson Correlation), which demonstrated a close relationship between reading ability and metacognitive awareness of reading strategies.

\section{B. Critical Thinking}

Our ever-changing and challenging world requires students, to go beyond the building of their knowledge; they need to develop their higher-order thinking skills, such as critical thinking, decision making, and problem solving (ProfettoMcGrath, 2003; Riddell, 2007; Sezer, 2008).

$\mathrm{Ku}(2009)$ States, "besides the ability to engage in cognitive skills, a critical thinker must also have a strong intention to recognize the importance of good thinking and have the initiative to seek better judgment".

Shirkhani \& Fahim (2011) believe that language learners who have developed critical thinking skills are capable of doing activities of which other students may not be capable.

Whereas earlier the teachers were at the center and the emphasis was put on what to teach, today's education involves teaching how to think, and how learners can be a critical thinker.

Birjandi and Bagherkazemi (2010) investigated the relationship between Iranian EFL teachers' critical thinking ability and their professional success. In this research measures of the critical thinking ability of some Iranian EFL teachers were obtained. Then, their professional success was estimated by their students through the Successful Iranian EFL Teacher Questionnaire (SIETQ). The result showed a statistically important relationship between the two sets of measures. Considering the result of this study, there is a need to accommodate 'critical thinking' as an essential aspect of EFL teacher education and teacher evaluation programs. According to this research better critical thinkers are better EFL teachers.

Ozkan (2010) believes that critical thinking has a vital role in education. He stated that student who thinks critically can ask suitable questions, gather relevant information, creatively sort through this information, reason from this information and come to reliable conclusions about the world that enable one to act successfully. These students are more productive while using their second language. This study showed how to develop critical thinking skills of English learners through critical thinking activities.

In another study by Aizikovitsh-Udi and Amit (2011) promotion of critical thinking by teaching specially designed learning unit was investigated. The purpose of this study was encouraging critical thinking dispositions such as openmindedness, truth-seeking, self confidence and maturity. The purpose of this study was to help composing new study programs and methods that can be based on the connection between critical thinking, creative thinking and the study of mathematics.

In another study by Marin and Halpern (2011) explicit and imbedded instructional modes were compared and critical thinking was assessed with Halpern Critical Thinking Assessment, which uses constructed response and multiple-choice response formats with everyday situations. In these two studies students who received explicit instruction showed better 
results than those in the imbedded instruction group. The results provided evidence that explicit instruction is an effective way for teaching critical thinking skills.

Shirkhani and Fahim (2011) investigated the improvements of critical thinking in foreign language learners. One factor that affects language learners' critical thinking skills is the assessment methods used. Then one of the ways in developing critical thinking is through managing the ways of assessing language learners' ability.

Yang and $\mathrm{Wu}$ (2012) had a year-long experimental study about the effect of digital storytelling (DST) for improving the academic achievement, critical thinking and learning motivation in students. The result of this study suggests that after twenty weeks of DST instruction, students showed improvement in English proficiency, critical thinking and learning motivation.

Fung and Howe (2012) emphasized the need for a learning environment that facilitates the practice of group work and the development of critical thinking. This article illustrated the importance of collaborative group work in the development of students' critical thinking skills. The participation of teachers in group discussion can also initiate students' dialogic interaction and consequently sharpen their critical thinking.

\section{Metacognition and Critical Thinking}

Schoen (1983) believes that critical thinking skills are facilitated through metacognition. He stated that "a successful pedagogy that can serve as a basis for the enhancement of thinking will have to incorporate ideas about the way in which learners organize knowledge and internally represent it and the way these representations change and resist change when new information is encountered" (p. 87).

Halpern (1998) represented metacognition and critical thinking together in a model. She stated that metacognition is the ability to use knowledge to direct and improve thinking skills. When learners are engaged in critical thinking, they need to do specific metacognitive skills such as monitoring thinking process, checking whether progress is being made toward an appropriate goal, ensuring accuracy, and making decisions about the use of time and mental effort. According to Mango this shows that critical thinking is a product of metacognition which provides a direction in the prediction of the two variables (Magno, 2010).

According to $\mathrm{Ku}$ and $\mathrm{Ho}$ (2010) metacognitive strategies used in critical thinking fall under three categories: planning, monitoring, and evaluating. Planning activities include those aiming at the determination of procedures that direct thinking, the selection of appropriate strategies, and the allocation of available resources (King 1991; Schraw 1998). Monitoring refers to an awareness of task comprehension (Schraw 1998). Monitoring activities are checking task information to validate comprehension and to devote attention to important ideas. Evaluating strategies involve the examination and correction of one's cognitive processes (Facione, 1990). These include evaluating one's reasoning and conclusions (Schraw, 1998). As a whole, a critical thinker is one who is in charge of his thinking processes, while metacognitive strategies enable this control to take place.

In another study by Choy and Cheah (2009) a more apparent connection between metacognition and critical thinking was found. Using a qualitative approach, they found that critical thinking is encouraged inside the classroom among the students when the teacher provides guidelines for them to use materials related to metacognition effectively. Specific strategies such as techniques, prompts, topics, and keywords are used in the class. These cognitive strategies and environmental structuring are specific metacognitive skills that are used to develop critical thinking. They concluded in their study that critical thinking requires higher level of cognitive skills such as metacognition in processing information

Lee (2009) examined the relationships between metacognition, self-regulation and critical thinking in online Socratic seminars for high school social studies students. First, he examined the effect of metacognition on students' selfregulation and critical thinking. Second, he investigated effects of metacognition as a moderator of the relationships between self-regulation and critical thinking integratively. Third, he investigated the relationship between selfregulation and critical thinking in both the experimental and comparison groups. Finally, he investigated the design and implementation of the two metacognitive tasks. Results of this study reveal the effect of metacognition tasks on students' development of self-regulation. He also showed the effect of the metacognitive tasks on students' selfregulation and potential to develop students' critical thinking.

In another study by Ku and Ho (2010) ten university students with comparable cognitive ability, thinking disposition and academic achievement but with different levels of critical thinking performance participated in this study. They were tested on six thinking tasks. Results of this study showed that good critical thinkers engaged in more metacognitive activities, especially high-level planning and high-level evaluating strategies.

Magno (2010) tested a model where metacognition was used to predict critical thinking. This prediction showed that the ability to monitor one's knowledge and thinking processes directs one to think critically. Magno structuring these two variables in a model establishes their theoretical link especially with the use of standardized measures. It is hypothesized in this study that critical thinking occurs when people use their metacognitive skills and strategies. The two models that were tested in this study: (1) In the first model, metacognition was composed of two factors (2) in the second model, metacognition had eight factors as they affect critical thinking. The results indicated that in both models, metacognition had an important way to critical thinking.

Valeh (2011) investigated about metacognitive strategy use and critical thinking among Science/Technology and Art/Humanities Students. She used two questionnaires. Two groups of Science/Technology and Arts/Humanities students were participated in this study. According to the results of this study there was a significant relationship 
between critical thinking dispositions and metacognitive strategy use. There was no significant difference between male/female, and Arts/Humanities and Science/Technology students in using metacognitive strategy and critical thinking dispositions and also, there was no significant difference between different levels of education.

\section{RESEARCH QUESTIONS}

1- Is there any significant relationship between intermediate EFL learners' critical thinking and their use of metacognitive strategies?

2- Does gender have any role in this respect?

\section{Methodology}

\section{A. Participants}

The participants of the study were 102 Iranian EFL students studying English at intermediate level at language institutes in Rasht. After the administration of The Barron's TOEFL and taking the results into account, the number of participants was reduced to 102. They were all learners of English, ranging from 15 and 23 years. 52 of the participants were male and 50 of them were female. They were studying Interchange book 2 at language institutes in Rasht.

\section{B. Instruments}

The instruments employed in this study include: Metacognitive Strategy Questionnaires by Item Type (MSQIT) (Purpura, 1999) to measure metacognition and California Critical Thinking Skills Test (CCTST) to measure critical thinking. MSQIT test consists of 40 items using three sub-scales: 1) goal setting processes (GS) 5-items, 2) planning processes (PL) 8-items, and 3) assessment processes (ASS) 27-items. CCTST test consists of 34 multiple-choice questions designed to measure critical thinking using two sub-scales. The primary sub-scale includes Analysis, Evaluation, Inference and the secondary subscale includes Deduction and Induction.

\section{Procedures}

In order to collect the necessary data, the following procedures were followed in this study. After selecting students based on the result of a Barron's TOEFL, 102students were selected to participate in this study. 52 of students were males and 50 of them were females. The purpose of this survey was to discover the relationship between critical thinking and metacognitive strategies in language learning. In doing so, the participants were requested to select the most appropriate answers to MSQIT and CCTST questions. First MSQIT questionnaire then CCTST questionnaire was given to the students. They answered to each questionnaire in 45 minutes. It was explained for the students how to fill up the answer sheets. Having collected the two completed questionnaires, the researcher checked whether the students have answered all the questions. Participants' identities were anonymous.

\section{Data Analysis}

After collecting the necessary data from the two sets of tests, the researcher ran the Pearson Product Moment Correlation Coefficient to find any possible relationship between the participants' critical thinking and metacognitive strategies. Furthermore, to find out whether the mean score of male participants' critical thinking is not different from the mean score of the female participants' critical thinking an Independent T-test was applied. Finally in order to see whether the mean score of male participants' metacognitive strategies was different from the mean score of the female participants' critical thinking another Independent T-test was performed.

\section{RESULTS}

In order to collect the necessary data, the two instruments were administered to the participants in one administration session.

The first research question investigated the relationship between male intermediate Iranian EFL learners' critical thinking and their use of metacognitive strategies.

Descriptive statistics of male participants' scores on metacognitive strategies (MSQIT) questionnaire are presented in Table 1.

TABLE 1

DESCRIPTIVE STATISTICS OF MALES' SCORES ON MSQIT QUESTIONNAIRE

\begin{tabular}{|l|l|l|l|l|l|l|l|l|}
\hline $\mathrm{N}$ & Range & Min & Max & Mean & Median & Mode & SD & Variance \\
\hline 52 & 84 & 110 & 194 & 151.52 & 151.50 & $135^{\mathrm{a}}$ & 20.86 & 435.39 \\
\hline
\end{tabular}

Descriptive statistics of male participants' scores on critical thinking (CCTST) questionnaire are laid out in Table 2. 
TABLE 2

DESCRIPTIVE STATISTICS OF MALES' SCORES ON CCTST

\begin{tabular}{|l|l|l|l|l|l|l|l|l|}
\hline $\mathrm{N}$ & Range & Min & Max & Mean & Median & Mode & SD & Variance \\
\hline 52 & 11 & 10 & 21 & 14.67 & 14.50 & 15 & 2.57 & 6.61 \\
\hline
\end{tabular}

Figure 1. Displays this relationship. This figure depicts that as the metacognitive strategies scores increase, the critical thinking scores enhances as well.

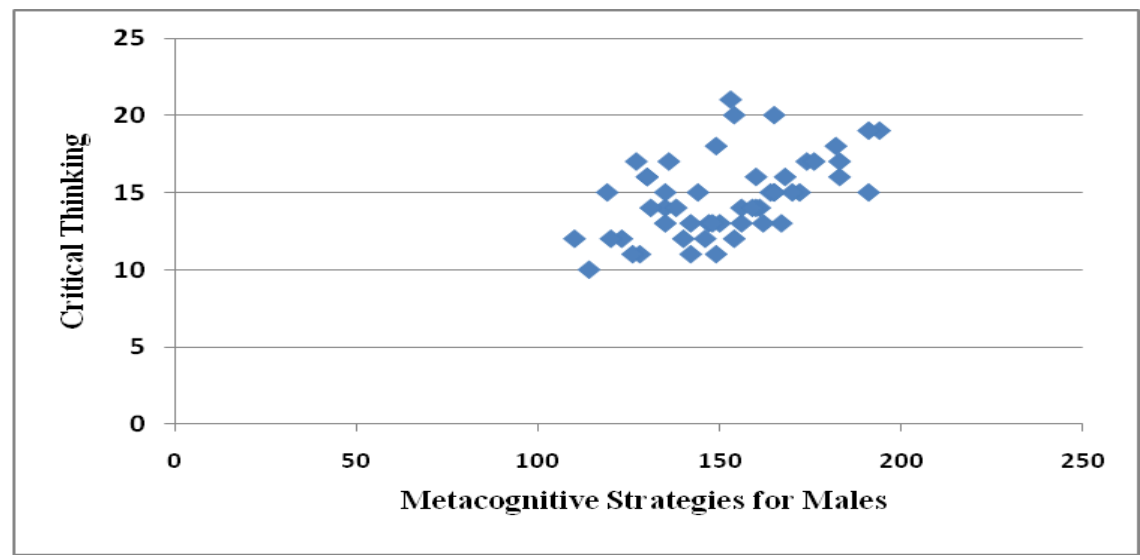

Figure 1. Correlations between Males' Scores on CCTST and MSQIT

The results of the Pearson Correlation procedure indicated a positive relationship between them. In other words, the findings revealed that the more metacognitive strategies increase in students, the more critical thinking enhances as well since a large positive correlation of .512 was observed between participants' metacognitive strategies and their critical thinking. The level of significance is .000 which is less than that of the chosen significance level, .05 $(P .<\alpha)$.

TABLE 3

CORRELATIONS BETWEEN MALES’ SCORES ON CCTST AND MSQIT

\begin{tabular}{|ll|l|l|}
\hline & & $\begin{array}{l}\text { Metacognitive Strategies } \\
\text { for Males }\end{array}$ & $\begin{array}{l}\text { Critical Thinking for } \\
\text { Males }\end{array}$ \\
\hline Metacognitive Strategies for Males & Pearson Correlation & 1 & $.512^{* *}$ \\
& Sig. (2-tailed) & 52 & .000 \\
& $\mathrm{~N}$ & $.512^{* *}$ & 52 \\
\hline \multirow{3}{*}{ Critical Thinking for Males } & Pearson Correlation & .000 & 1 \\
& Sig. (2-tailed) & 52 & 52 \\
\hline
\end{tabular}

The second research question focused on the investigation of the whether there is a relationship between female intermediate Iranian EFL learners' critical thinking and their use of metacognitive strategies and Pearson Product Moment Correlation was performed.

Descriptive statistics of female participants' scores on metacognitive strategies questionnaire are given in Table 4.

TABLE 4

DESCRIPTIVE STATISTICS OF FEMALES' SCORES ON MSQIT

\begin{tabular}{|l|l|l|l|l|l|l|l|l|}
\hline $\mathrm{N}$ & Range & Min & Max & Mean & Median & Mode & SD & Variance \\
\hline 50 & 83 & 102 & 185 & 142.7 & 142.00 & $126^{\mathrm{a}}$ & 20.33 & 413.49 \\
\hline
\end{tabular}

Table 5 sets forth the descriptive statistics of female participants' scores on critical thinking questionnaire.

TABLE 5

DESCRIPTIVE STATISTICS OF FEMALES 'CCTST QUESTIONNAIRE

\begin{tabular}{|l|l|l|l|l|l|l|l|l|}
\hline $\mathrm{N}$ & Range & Min & Max & Mean & Median & Mode & SD & Variance \\
\hline 50 & 10 & 9 & 19 & 13.20 & 13.00 & 13 & 2.41 & 5.83 \\
\hline
\end{tabular}

Figure 2 displays this relationship. This figure depicts that as the metacognitive strategies scores increase, the critical thinking scores enhances as well. 


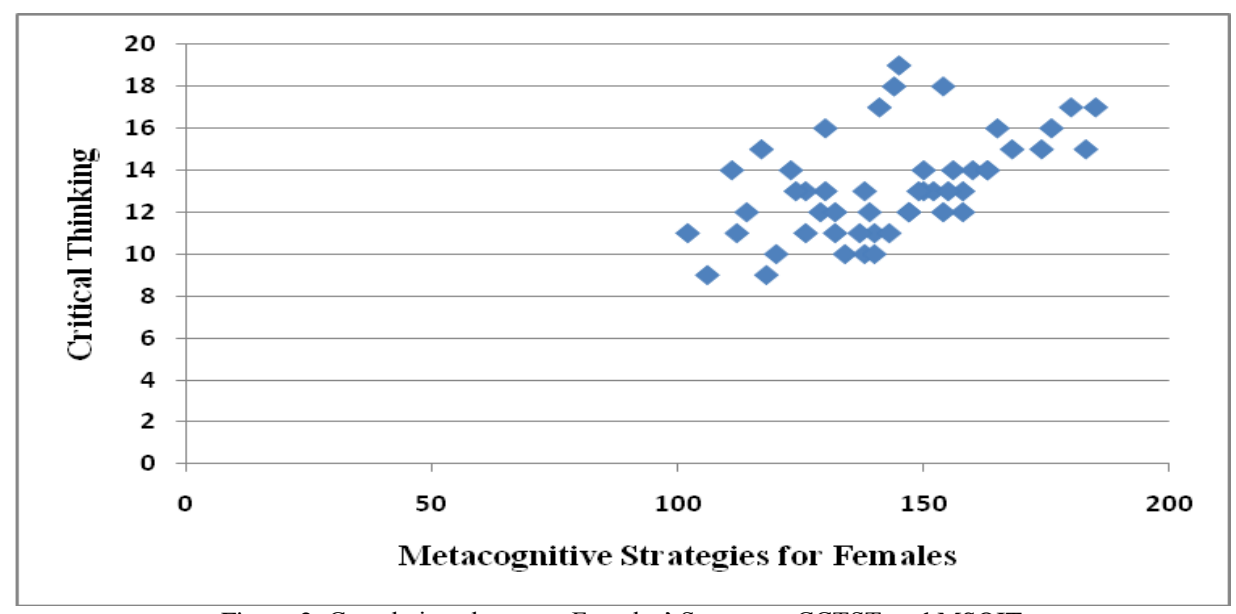

Figure 2. Correlations between Females' Scores on CCTST and MSQIT

Table 6 reveals this relationship. The results revealed that there is a large significant relationship between intermediate Iranian EFL learners' critical thinking and their use of metacognitive strategies for females and language learning. A large positive correlation of .533 was discovered between female participants' metacognitive strategies and their critical thinking. The level of significance is .000 which is less than that of the chosen significance level, .05 (P. $<$ $\alpha)$.

TABLE 6

CORRELATIONS BETWEEN FEMALES' SCORES ON CCTST AND MSQIT

\begin{tabular}{|ll|l|l|}
\hline & & $\begin{array}{l}\text { Metacognitive Strategies } \\
\text { for Females }\end{array}$ & $\begin{array}{l}\text { Critical Thinking for } \\
\text { Females }\end{array}$ \\
\hline Metacognitive Strategies for Females & Pearson Correlation & 1 & $.533^{* * *}$ \\
& Sig. (2-tailed) & .000 & 50 \\
Critical Thinking for Females & $\mathrm{N}$ & 50 & 1 \\
& Parson Correlation & $.533^{* *}$ & 500 \\
& Sig. (2-tailed) & 50 & 50 \\
\hline
\end{tabular}

In order to figure out whether the critical thinking scores are normally distributed, we used Kolmogorov-Smirnoff non-parametric test. Table VII manifests that the Sig. for males and females showed .41 and .33 respectively based on the data which we may consider that the scores are normally distributed. The assumption of normal distribution is not violated since Sig. was higher than .05. Therefore the parametric independent T-test was run to analyze the data.

TABLE 7

ONE-SAMPLE KolmOgOROV-SMIRNOV to TEST NORMALITY OF MALES AND FEMALES’ SCORES ON CCTST QUESTIONNAIRE

\begin{tabular}{|ll|l|l|}
\hline \multicolumn{1}{|c|}{ Critical Thinking } & & Males & Females \\
\hline $\mathrm{N}$ & & 52 & 50 \\
Normal Parameters & Mean & 14.67 & 13.20 \\
& Std. Deviation & 2.572 & 2.416 \\
Most Extreme Differences & Absolute & .123 & .133 \\
& Positive & .123 & .133 \\
Kolmogorov-Smirnov Z & Negative & -.057 & -.062 \\
Asymp. Sig. (2-tailed) & & .883 & .940 \\
\hline
\end{tabular}

To see whether the metacognitive strategies scores are normally distributed, we used Kolmogorov-Smirnoff nonparametric test. Table 8 hands on that, the sig for males and females showed .95 and .97 respectively based on the data which we may consider that the scores are normally distributed. Since Sig. was more than .05, the scores are normally distributed for both male and female participants. Therefore the parametric independent $T$-test was carried out to analyze the data. 
TABLE 8

ONE-SAMPLE KOLMOGOROV-SMIRNOV TO TEST NORMALITY OF MALES AND FEMALES' SCORES ON MSQIT QUESTIONNAIRE

\begin{tabular}{|ll|l|l|}
\hline Metacognitive Strategies & & Males & Females \\
\hline $\mathrm{N}$ & & 52 & 50 \\
Normal Parameters & Mean & 151.52 & 142.76 \\
& Std. Deviation & 20.866 & 20.335 \\
Most Extreme Differences & Absolute & .060 & .042 \\
& Positive & .060 & .042 \\
Kolmogorov-Smirnov Z & Negative & -.044 &. .038 \\
Asymp. Sig. (2-tailed) & & .432 & .295 \\
\hline
\end{tabular}

Then the possible difference between male and female participants' critical thinking and metacognitive strategies scores was investigated. As mean score of two independent groups was to compare and scores of two groups had normal distributions, two Independent T-tests were carried out.

According to this investigation, it was concluded that the mean score of male participants' critical thinking is significantly more from the mean score of the female participants' critical thinking and also mean score of male participants' metacognitive strategies is significantly more from the mean score of the female participants' metacognitive strategies.

\section{DISCUSSION}

To calculate the relationship between two variables of this study, Pearson product-moment correlation coefficient was applied. The correlation between male intermediate Iranian EFL learners' critical thinking and their use of metacognitive strategies was .51, while for females it was slightly higher, $\mathrm{r}=.53$. The $p$ value for correlation between variables for both males and females was .000. The level of significance does not indicate how strongly the two variables are associated, but instead it indicates much confidence should be had in the results obtained.

Figure 3 shows the relationship between intermediate Iranian EFL learners' critical thinking and their use of metacognitive strategies for males was .51 . However it was .53 for females.

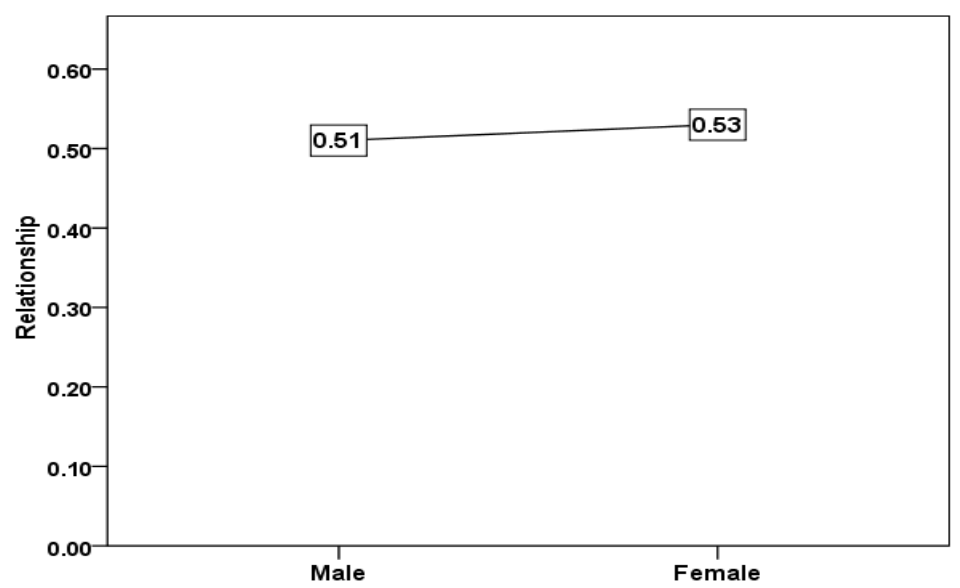

Figure 3. the relationship between critical thinking and metacognitive

Different authors interpret the value of correlation differently; however, Cohen (1998, pp.79-81) suggests the following guidelines:

\begin{tabular}{|ll|}
\hline Small & $\mathrm{r}=.10$ to .29 \\
Medium & $\mathrm{r}=.30$ to .49 \\
large & $\mathrm{r}=.50$ to 1.0 \\
\hline
\end{tabular}

In this study, there is a large correlation between the two variables for both males and females, suggesting quite a strong relationship between intermediate Iranian EFL learners' critical thinking and their use of metacognitive strategies for both males and females.

The results of this study are in line with Özkan' (2010) idea that a student who thinks critically can ask good questions, gather relevant information, efficiently and creatively sort through the present information, reason logically from this information, and come to reliable and trustworthy conclusions about the world that enable one to live and act successfully. Therefore, they are more productive while using their second language. 
The results of this study also correlates with Soden's (2000) findings that critical thinking encompasses a number of abilities such as identifying a problem and the assumptions on which it is based, focusing the problem, analyzing, understanding and making use of inferences, inductive and deductive logic, and judging the validity and reliability of assumptions and sources of data. The present study is compatible with the study of Kogut (1996), who found specific strategies that improve critical thinking which are metacognitive in nature. The results of the present study are also in line with those of Kuhn and Dean (2004) who found explicit use of metacognition to achieve critical thinking in the context of a debate. They found that in understanding an opponent's argument and making one's counterargument requires the debater to do deep level of processing or metacognition that help the individual decide to continue or withdraw certain behaviors in achieving a goal. In addition, the findings of the present study corroborate those of Orion and Kali (2005) who showed a connection between metacognition and thinking skills using a qualitative analysis approach. At the same time, the present study is in accordance with those of Choy and Cheah (2009) who reported a connection between metacognition and critical thinking. They found that critical thinking is encouraged inside the classroom among the students when the teacher provides guidelines for them to use materials related to metacognition effectively. Magno (2010) also obtained the same result as he tested a model where metacognition was used to predict critical thinking. This prediction showed that the ability to monitor one's knowledge and thinking processes helps one to think critically.

This finding supports another investigation by Valeh (2011) who found a significant relationship between critical thinking dispositions and metacognitive strategy use.

\section{CONCLUSION}

The present study attempted to study on the effect of two variables, metacognition and critical thinking and their effect on students' language learning. The first research question sought to investigate the relationship between male intermediate Iranian EFL learners' critical thinking and their use of metacognitive strategies. The results of the Pearson Correlation procedure indicated a positive relationship between them. In other words, the findings revealed that the more metacognitive strategies increase in students, the more critical thinking enhances as well. The second research question focused on the investigation of the whether there is a relationship between female intermediate Iranian EFL learners' critical thinking and their use of metacognitive strategies and Pearson Product Moment Correlation was performed. The results revealed that there is a large significant relationship between intermediate Iranian EFL learners' critical thinking and their use of metacognitive strategies for females and language learning.

Then the possible difference between male and female participants' critical thinking and metacognitive strategies scores was investigated. As mean score of two independent groups was to compare and scores of two groups had normal distributions, two Independent T-tests were carried out.

According to this investigation, it was concluded that the mean score of male participants' critical thinking is significantly more from the mean score of the female participants' critical thinking and also mean score of male participants' metacognitive strategies is significantly more from the mean score of the female participants' metacognitive strategies.

\section{REFERENCES}

[1] Aizikovitsh-Udi, E., \& Amit, M. (2011). Developing the skills of critical and creative thinking by probability teaching. Procedia Social and Behavioral Sciences 15, 1087-1091.

[2] Birjandi, P. \& Bagherkazemi, M. (2010). The relationship between Iranian EFL teachers' critical thinking ability and their professional success. English Language Teaching, 3.2, 135-145.

[3] Choy, S. C. \& Cheah, P. K. (2009). Teacher perceptions of critical thinking among students and its influence on higher education. International Journal of Teaching and Learning in Higher Education, 20.2, 198-206.

[4] Cohen, A. D. (1998). Strategies in learning and using a second language. Harlow: Longman.

[5] Facione, P. A. (1990). Critical thinking: A statement of expert consensus for purposes of educational assessment and instruction-executive summary of the Delphi report. Millbrae: California Academic Press.

[6] Flavell, J. H. (1979). Metacognition and cognitive monitoring: a new area of cognitive-developmental inquiry. American Psychologist, 34, 906-911.

[7] Fung, D., Howe, C. (2012). Liberal Studies in Hong Kong: A new perspective on critical thinking through group work. Thinking Skills and Creativity 7, 101- 111.

[8] Halpern, D. F. (1998). Teaching for critical thinking: helping college students develop the skills and dispositions of a teaching critical thinking for transfer across domains: dispositions, skills, structure training, and metacognitive monitoring. The American Psychologist, 53, 449-455.

[9] Iwai, Y. (2011). The Effects of Metacognitive Reading Strategies: Pedagogical Implications for EFL/ESL Teachers. The Reading Matrix, Volume 11, Number 2, 150-159.

[10] King, A. (1991). Effects of training in strategic questioning on children's problem-solving performance. Journal of Educational Psychology, 83.3, 307-317.

[11] Ku, K. Y. L. (2009). Assessing students' critical thinking performance: Urging for measurements using multi-response format. Thinking Skills and Creativity, 4, 70-76, doi: 10. 1016/j.tsc.2009.02.001.

[12] Ku, K. Y. L., \& Ho, I. T. (2010). Metacognitive strategies that enhance critical thinking. Metacognition and learning, 5.3, 251267. 
[13] Lee, S. T. (2009). Examining the Relationships between Metacognition, Self-regulation and Critical Thinking in Online Socratic Seminars for High School Social Studies Students. Presented to the Faculty of the Graduate School of The University of Texas at Austin in Partial Fulfillment of the Requirements for the Degree of Doctor of Philosophy p. 185.

[14] Magno, C. (2010). The role of metacognitive skills in developing critical thinking. Metacognition Learning. 5,137-156.

[15] Marin, L. M. \& Halpern, D. F. (2011). Pedagogy for developing critical thinking in adolescents: Explicit instruction produces greatest gains. Elsevier journal, Thinking Skills and Creativity 6, 1-13.

[16] Noroozi Siam. E., Soozandehfar, S. M. A. (2011). Metacognitive awareness of reading strategies and reading comprehension. California Linguistic Notes. Volume XXXVI No 1, p.12.

[17] Özkan, I., (2010). Telling ELT Tales out of School A path to critical thinking. Science Direct. Procedia Social and Behavioral Sciences 3, 210-212.

[18] Pellegrino, A. M. (2007). The Manifestation of Critical Thinking and Metacognition in Secondary American History Students through the Implementation of Lesson Plans and Activities Consistent With Historical Thinking Skills. Thesis of Doctor of Philosophy (P.152). Full Text.(Publication No. AAT 3282653).

[19] Profetto-McGrath, J., (2003). The Relationship of Critical Thinking Skills and Critical Thinking Dispositions of Baccalaureate Nursing Student, Journal of Advanced Nursing, 43.6, 569-577.

[20] Purpura, Jemes E. (1999). Studies in Language Testing. UK: Cambridge University Press, PP. 3-6, 12, 184, $222-6$.

[21] Rahimi, M. and Katal, M. (2010). Iranian university students' metacognitive listening strategies awareness in learning English. Paper presented at the third national conference on education, Tehran, Iran.

[22] Riddell, T. (2007). Critical assumptions: Thinking critically about critical thinking. Journal of Nursing Education, 46.3, 121126.

[23] Sandí-Ureña, G. S. (2008). Design and Validation of a Multimethod Assessment of Metacognition and Study of the Effectiveness of Metacognitive Interventions. ProQuest Dissertations and Theses; Thesis (Ph.D.) - Clemson University, Publication Number: AAI3316275; ISBN: 9780549690405; Source: Dissertation Abstracts International, Volume: 69-08, Section: B, page: $4717 ; 175 \mathrm{p}$.

[24] Schoen, D. (1983). The reflective practitioner. San Francisco: Jossey-Bass.

[25] Schraw, G. (1998). Promoting general metacognitive awareness. Instructional Science, 26, 113-125.

[26] Sezer, R. (2008). Integration of Critical Thinking Skills into Elementary School Teacher Education Courses in Mathematics. Education, 128.3, 349-362. Proquest education journals.

[27] Shirkhani, S. \& Fahim M. (2011). Enhancing critical thinking in foreign language learners. Procedia - Social and Behavioral Sciences 29, $111-115$.

[28] Sternberg, R. J. (1998). Metacognition, abilities and developing expertise: What makes and expert student? Instructional Science 26.1-2, 127-140.

[29] Taylor, S. (1999). Better learning through better thinking: Developing students' metacognitive abilities. Journal of College Reading and Learning, 30.1, 34ff. Retrieved November 9, 2002, from Expanded Academic Index ASAP.

[30] Torkamani, H. T. (2010). On the use of metacognitive strategies by Iranian EFL learners in doing various reading tasks across different proficiency levels. International Journal of Language Studies (IJLS), Vol. 4.1, pp. 47-58.

[31] Valeh, M. (2011). Metacognitive Strategy Use and Critical Thinking among Science/Technology and Arts/Humanities Students. A thesis for the degree of Master of Arts in Teaching English as a Foreign Language (TEFL). University of Tehran Kish International Campus. p. 107.

[32] White, R. T. (1988). Metacognition. In J. P. Keeves (Ed.), Educational research, methodology, and measurement (pp. 70-75). Sydney: Pergamon Press.

[33] Winne, P. H. \& Hadwin, A. F. (1998). Sudying as self-regulated learning. In D. J. Hacker, J. Dunlosky \& A. C. Graesser (Eds.), Metacognition in educational theory and practice (pp. 277-304). Mahwah, NJ: Lawrence Erlbaum Associates.

[34] Yang, Y. C. \& Wu, W. I. (2012). Digital storytelling for enhancing student academic achievement, critical thinking, and learning motivation: A year-long experimental study. Elsevier journal, Computers \& Education 59, 339-352.

[35] Young, D. J. (1991). Creating a low-anxiety classroom environment: what does the language anxiety research suggest? Modern Language Journal, 75.4, 426-437.

Bahador Sadeghi, an assistant professor of Applied Linguistics holds a doctorate degree in TEFL from the University of Isfahan, Iran. He also holds three MAs in TEFL, English Translation and International Relations from Tehran Islamic Azad University, Isfahan University and Allameh Tabatabai University respectively. He has been lecturing different subjects in TEFL, Translation studies, General English and ESP at several universities in Iran for the last twenty years. He has both published and presented a number of articles in some international journals and conferences. He has translated twenty books from English to Persian. He is also a certified translator to the judiciary power in Iran and he has been, as a simultaneous interpreter, actively involved in many national and international seminars, sport events and tourism projects.

Mohammad Taghi Hassani, assistant professor in TEFL at Imam Hossein University, Tehran and Islamic Azad University, Takestan Branch, Iran. His research interests are EFL writing, psycholinguistics, phonetics, contrastive analysis, English for Specific Purposes, and language teaching methodology.

Masoumeh Rahmatkhah received her MA in 2013 in TEFL from the Department of English Language at Islamic Azad University of Takestan. She is currently teaching English at high schools and English language institutes. 